\title{
The Role of Social Media in Promoting Tourist and Heritage Sites "A case study of Al-Mu'izzLedin Allah Street"
}

\author{
Alaa Mohamed Azazz \\ Lecturer - Tourism Studies department \\ Faculty of Tourism and Hotels, Suez Canal University
}

\author{
Esraa Ahmed El labban \\ Lecturer-Guidance Studies department \\ Faculty of Tourism and Hotels, Suez Canal University
}

\begin{abstract}
This paper aims at exploring the role of social media in promoting thetourist and heritage sites in Egypt.

The data were collected offline and online through an online survey from users of AlMu'izz Facebook pages and a printed version of the questionnaire was distributed to 350 tourists who visitedAl-Mu'izzStreet. Data were analyzed using (SPSS).

This paper provides evidence that supports the positive impact of social media (Facebookpages ) from the tourist's perspective on promoting heritage sites in Egypt.
\end{abstract}

Keywords -Social Media, tourism promotion, Facebook, heritage sites, Al-Mu'izz Li-din Allah Street

\section{Introduction}

Tourism is considered as an important source of economy, which continues to grow rapidly. It is considered as a good opportunity for development in many countries (Guzzo et al., 2013). Tourism was always one of the main significant elements of the electronic commerce world, which may affect the structure of the tourism business. Online travel has witnessed the development of new consumer behaviors and promoting tools (Klein, 1999; Werthner\& Ricci, 2004; Milano\&Piattelli, 2011).

Social Networking is a vital instrument to advertise good things about destination and people. Thus, Social media has a significant role in promoting tourism through different network sites where tourists generally communicate and involve (Buted etal., 2014; Madondo, 2016).Accordingly, Tourism marketers are also noticeably using social networking to communicate with actual and potential travelers during the decision-making process (Hudson \& Thal, 2013).

Furthermore, the increasing numbers of users to the internet applications enable various tourism organizations like airline companies, hotels and travel companies to start using the internet as a competitive strategy (Sahin \& Sengün, 2015).

More specific, Facebook has attained a leading position and is considered to be the most widespread social media website ever. It has become a key reference mean in online travel and tourism industry, employed by customers in any stage of the decision buying process (Fotis et al., 2012; Bulencea \& Egger, 2013). 
Several empirical studies have measured the role played by Facebook and other social media in the supply and demand of the ETourism market and have revealed the significance which attained by these platforms in the tourism industry (Milano et al.,2011; Zeng \& Gerritsen, 2014; Mich \& Baggio, 2015).Therefore, social network sites can be employed as a new marketing technique in increasing online technologies by the tourism industry (Sahin \& Sengün, 2015). Moreover, its role has been investigated mainly from a marketing perspective (Kotler et al, 2014).

The above discussion shows the importance of social media as a new marketing tool in promoting tourist sites. In this vein, the current study aims at exploring the role played by social media in promoting heritage sites applied on Al-Mu'izz Street-Egypt.

\section{Social media}

Socialmedia is" a catchphrase that describes technology that facilitates interactive information, user-created content and collaboration" (Elefant, 2011, p. 4; Seth, 2012). WhileMayfield (2008, p.4) stated that social media "is a two-way conversation when comparing to traditional media because social media outlets are open up to feedback and participation".

Kaplan \& Haenlein (2010) classified social media into six fields: virtual social worlds, social networking sites, blogs, content communities, collaborative projects and virtual game worlds. For examples customers use social networks like Wikipedia for (reference), Facebook for (social activity), YouTube for (sharing videos) and Trip Advisor (for travel networks) which let them see reviews and comments of other actual customers, thus, today information is considerably perceived in different ways (Weinberg, 2009 and Seth, 2012).

Facebook is one of the most important types of social media. Facebook reached 1.15 billion users in 2013(Bulencea\& Egger, 2013) and according to Facebook Pages guide in 2018 more than 20 million people used Facebook every day. More than half of them connect with their pages every day and spend about nineteen minutes a day on Facebook (O'Connor, 2011and Merello, 2018).The statistic website showed a timeline with the worldwide number of monthly active Facebook users from 2008 to 2018 which indicated that the number of Facebook monthly active users reached 2.23 billion in the second quarter of 2018 and about 52 percent of Facebook users stated that photos on Facebook encouraged them to travel to a certain destination (Wittman, 2012; Bulencea \& Egger, 2013).

As the number of users increased and the awareness level of the consumers increased, these sites created online communities of users share activities, experiences and interests. Thus, the leisure time to communicate socially has become more suitable as communication became faster, easier and cheaper (Choustis, 2013). Therefore, a high number of tourists use the internet to find information about their destination, accommodation, transportation or activities before making purchases (Litvin et al., 2008; Xiang\&Gretzel, 2010; Milwood et al., 2013).

According, to the important role of social media to communicate and involve with tourists, tourism marketers need to raise their level of online commitment and transform their marketing strategies to the online environment (Madondo, 2016). 


\section{Tourism Promotion}

Promotion can be defined as the "function of informing, persuading and influencing a consumer decision" equally important for nonprofit and profit organizations and equally important for products or services. Promotion can be used to increase sales, attract new customers, create awareness, change the attitude or create an image, through advertising, personal selling, public relations, publicity, direct marketing and sales promotion and interactive/internet marketing (Esu\&Ebitu, 2010).

The promotion has a significant effect on the purchase decision of services, products, or the choice of a specific destination. The importance of promotion comes from its ability to increase the awareness and interest in the destination, display its attractiveness, differentiate the destination from competitors, enhance the image of the destination and it can also encourage travelers to stay longer (Esu\&Ebitu, 2010)

Destination promotion process occurs in a variety of ways, for example, across adverts, websites, social networks, brochures, travel journals and marketing specialized agencies. Promotion in tourism plays a hugely valuable portion and emphasizes the interaction between both supply and demand (Rodrigues, 2017).

Promoting a tourist destination is not an easy task. Its difficulties derive from the nonhomogeneous request of travelers and multiattributed nature of the destination (Butedet al., 2014). Therefore, the development of information and communication technologies, especially the internet has a strong influence on changes in the use of marketing (Popesku, 2014).

\section{Social media and Tourism promotion:}

The intangibility of tourist products and hospitality made them hard to be evaluated before their use and are high-risk purchases (Lewis \& Chambers, 1999).The marketing activities in the tourist destinations are designed to shore up the basics of the destination in attracting the expected tourists to come and see it, to use its services and proofing that their visit's expectations met those of the destination (Popesku, 2014).

As stated by Dickman and Maddock (2000) tourism can be promoted when there is effective communication with the potential and actual tourists. The marketer can use different elements of the promotional mix to promote either a service or a product. Despite the excess marketing tools existing to promote tourism, social media has become the most effective tool for generating awareness and creating interest in a product (Waxer, 2012; Madondo, 2016).

Commonly, the electronic media is preferred more than the printed media and has a greater influence on tourists' decisions. More specific, social media is considered to be the most effective tool than all other types of media. Therefore, marketers in hospitality industry prefer using social media as a mean to promote destinations and enhance performance (Park, 2015).

Social media use is growing, and the destination marketing organizations challenge is to efficiently select not only the applications they need, but also to recognize the needs of their consumers from their sites and the essentials to be included in their website that will successfully affect the decision making of the traveler, socially, practically and accurately (Wendy and Statia,2012). 
The internet has changed from the world of information to the world of persuading at the same time and its elements like the social media "start to revolutionize the state of marketing, advertising, and promotions. (Hanna et al, 2011).

Travel websites like Trip Advisor, Expedia and booking.com, as well as social networking platforms (Facebook and Twitter) currently play a key role in online communications among travelers (Kim, Lim, \& Brymer, 2015). $\mathrm{We}$ are in front of user-friendly platforms, where travelers can easily find or share comments, opinions, photos and videos about their travel experiences (Merello, 2018; Papathanassis \& Knolle, 2011). For instance, nearly $70 \%$ of tourists consult the experiences of other customers to take a decision (Minazzi \& Lagrosen, 2013).

According to (Milano \& et al, 2011) However, most of the studies have evaluated the social and psychological impacts and most of them confirmed the role of social as sources of information and others related to discussing various topics related to travels and holidays (Chung \& Buhalis, 2008; Schmallegger \& Carson, 2008; Inversini \& Buhalis, 2009; Xiang \& Gretzel, 2010 ; Parra-Lopez et al., 2010; Kasavana et al., 2010).

Many studieswere conducted to explore the impact of social media tools on the destination image (Burgess \& et al., 2009; Inversini \&et al., 2009; Matloka \& Buhalis, 2010; Sigala, 2010).Other studies highlighted the impact of the social media on the loyalty of the brand, as well as its influence on hotels' sales (Dellarocas, 2003; Litvin et al., 2008; Ye et al., 2009).While, some authors have focused their study on hotels websites' evaluation (Wan, 2002; Wong \& Law, 2005andEscobar \& Carvajal, 2013).
Other studies argued that while many hotels have pages on Facebook, most of them are quite unseen and did not reach high levels of activity and engagement (O' Connor, 2011). Despite, the importance of social media, most tour operators have not entirely estimated the role of this new technological world and still have many concerns about it (Milanoet al., 2011).

Platforms analysis is considered to be one of the most employed tools to measure social media influences and to analyze the visibility, interactivity and profile performance of Facebook pages, such as Facebook Insights, Fanpage karma and the other Analytics, which helps the examination of different key performance indicators (KPIs). KPIs is a metric that determines the success of marketing strategies. Quaintly website emphasized that KPIs numbers maybe different according to ones social media marketing strategy, on ones specific needs, goals and depends on the KPIs that matters for ones clients. Accordingly, Benea (2014) stated that KPIs are the number of followers, the level of engagement in their pages from the number of likes, shares, comments and the views followers do for the social media posts. While Megalytic website stated that the common Facebook KPIs are Page Likes, Page Reach (which tell how many people are exposed to the posts across Facebook) and Website Traffic from Facebook (If the post was linked back to the site on Facebook) one of the most useful measurements for any marketer is assessing how well these posts contribute to the overall website traffic).

Thus, the difference between being on Facebook and succeeding on Facebook is largely about identifying KPIs and framing everything, from posting to reporting, around those metrics. 
This study focused on five central social media metrics that could be used as ones KPIs, Number of fans, People talking about pages, People checked in the page, Profile Performance and engagement percentage of Al-Mu'izz Street Facebook pages.

\section{Al-Mu'izz Li-din Allah Street}

Al-Mu'izzStreet, named after the fourth Fatimid Imam-caliph al-Mu'izz li-Din Allah (953-975 CE), who ruled Egypt for 22 years from $953 \mathrm{AD}$ and ordered the construction of the new capital Cairo, The street is also known as the qasaba street and by al-Karyn, It is almost certainly the oldest street in Cairo, it extends to one kilometer long, running through the central core of Islamic Cairo, it starts at $\mathrm{Bab}$ Al-Fotuh in the north and ends at Bab Zoweila in the south, according to a UN study it encloses the largest medieval architectural treasures concentration .In the Islamic world, this street held all the important celebrations of the Fatimid caliphs (Hristova;Czepczyński, 2017, p. 111).

In the Fatimid Era "Al-Mu'izz Street was restricted to the elite of society and and the royal family members, whose architectural constructions lined both sides of the street. Here is where Sultans paraded when they took over the regency" (Mehrez, Samia, 2010, p. 42).

"The street in the Fatimid era was a cultural and educational center with a great library. By the time, prosperous merchants replaced the original residents of the street". (Antoniou, 1998, pp.32-35)

"After the successive Sunni caliphates regained control on the city of Cairo, much of the Fatimid capital was destroyed, Al-Mu'izz Street kept its importance. most of the mosques, wikala, madrassa, sail and other architectural construction of the Ayyubid,
Mamluk, Ottoman rulers who reigned Egypt after the Fatimids were constructed along this street through the heart of the city" (Hristova;Czepczyński, 2017, p. 112).

Besides, the extraordinary monuments spread along the length of the street; it hosts a bustling district in which there are homes for thousands of craftsmen who make goods to be sold in the commercial node of Khan AlKhalili, the old market which characterizes the midpoint of the street (Sayyed, 1981, p.93).

In 1997, the national government carried out massive restoration and preservation operation for the historical buildings, modern buildings, land escaping, street pavement and repairing the sewerage system and installation of LED lightsturning the street to an "outdoor museum" that demonstrates the flourish of a civilization where ideologies, religious believers and even individuals living at this time are preserved in its essence (Mehrez \& Samia, 2010, p. 44).

The surrounding building of the street was raised in their current condition and then they underwent restoration that took them back to their original glory by tearing down any existing infringements and redesigning the existing commercial facades to reflect the typical character of the space while maintaining the unique character of it, completing the original image created along the time (Sedky, 2009, p.183).

The Street was reopened on April 24, 2008, as a walker zone from 8:00 am to11:00 pm; while the good traffic is permitted only outside these hours (Lababidi, 2008, pp. 17-19).

The northern part of the street extends from Al-Hakim Mosque in the north to Al-Azhar Street which includes the markets of spices, textiles, it comprises the following monuments: (Sedky, 2009, p.184) (Plate 1) 
- Bab Al-Futuh (1087 AD)

- Al-Hakim Bi Amr Allah mosque (1013 AD)

- Wikalat Al-sultan Al-Mansour Qaytbay (1481AD)

- Wikalat Al-AmirQawsum (1330 AD)

- Mosque, sabil,and kuttab of Sulayman Agha al-Silahdar (1839 AD)

- Bayt al-Shaymin (1648-1796 AD)

- Al-Aqmar mosque (1125 AD)

- Al-Amir Bashtak Palace (1339 AD)

- Al Madrasa al family (1229 AD)

- The Sabil-Kuttab of Abdel Rahman Katkhuda (1744AD)

- Sabil of Ismail Pasha (18281829 AD)

- Mosque and madrassa of al-Zahir Barquq (1386-1384 AD)

- Madrasa of Al-Nasir Muhammad bin Qalawun(1304AD)

- Qubba, Madrassa, and Bimarestan of Al-Mansour Qalawun (1285 AD)

- Madrassa and Qubba of Al-Salih Najm Al-Din Ayub (1250 AD)

- Hamam of Sultan Al-Ashraf Aynal (1456 AD)

- Sabil-Kuttab of khusrw Pasha (1535 AD)

- Mosque-Madrassa of Al-Ashraf Barasbay (1424 AD)
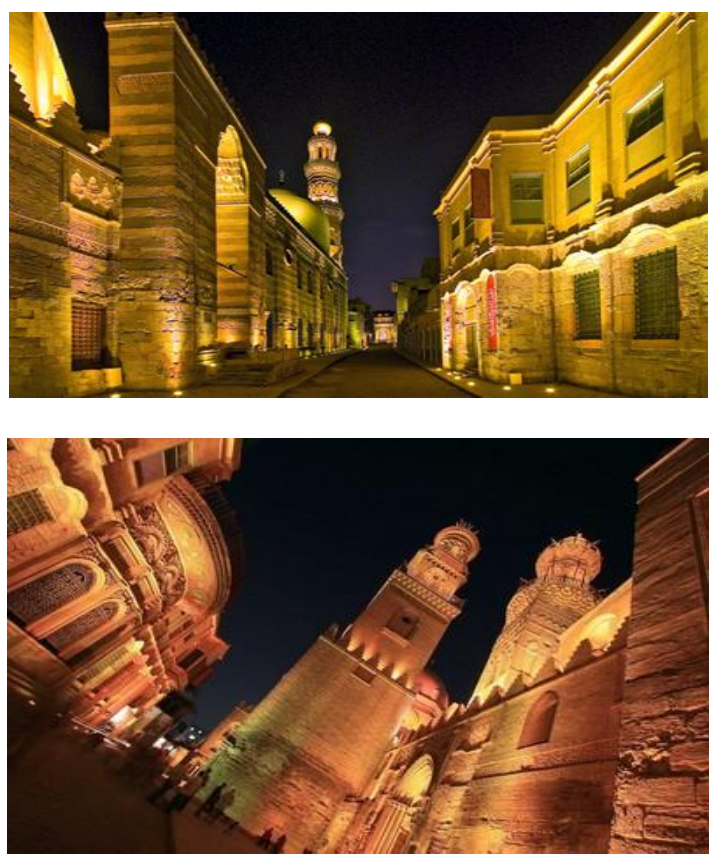

figure (1) The northern part of Al-Mu'izz Street
The southern part of the street stretches from the complex of Sultan al Ghuri to Bab Zoweila and includes the splendid Tent Market in AlGamaliya quarter and the following monuments:

- Madrassa-Mosque of Sultan Al-Ghaury (1505 AD)

- Mausoleum of Sultan Al-Ghaury(1505 $\mathrm{AD})$

- Wikala of Al-Sultan Al-Ghaury(1505 $\mathrm{AD})$

- Mosque of Al-Lakhani (1735 AD)

- Sabil of Mohamed Aly (1820 AD)

- Mosque of Sultan Al-Muaayad Shaykh(1415-1420 AD)

- Wikala and Nafisa Al-Bayda (1796 AD)

- Sabil of Nafisa Al-Bayda (1796 AD)

- Bab Zuweila (1092 AD)

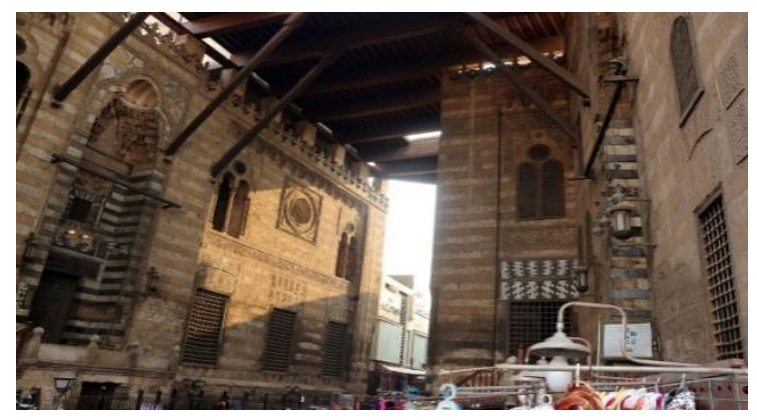

figure (2) The southern part of Al-Mu'izz Street

The social media, especially Facebook played a vital role in promoting the street and rediscovering it. Many pages and groups were created to show its historical value, in which people are sharing information and photos about the street.

Some pages go further and organized free tours of the street, in which there is a guide to explain the archeological and historical sites in it. These tours met a big turnout and the number of people joining it increases over time, (Plate 2). 

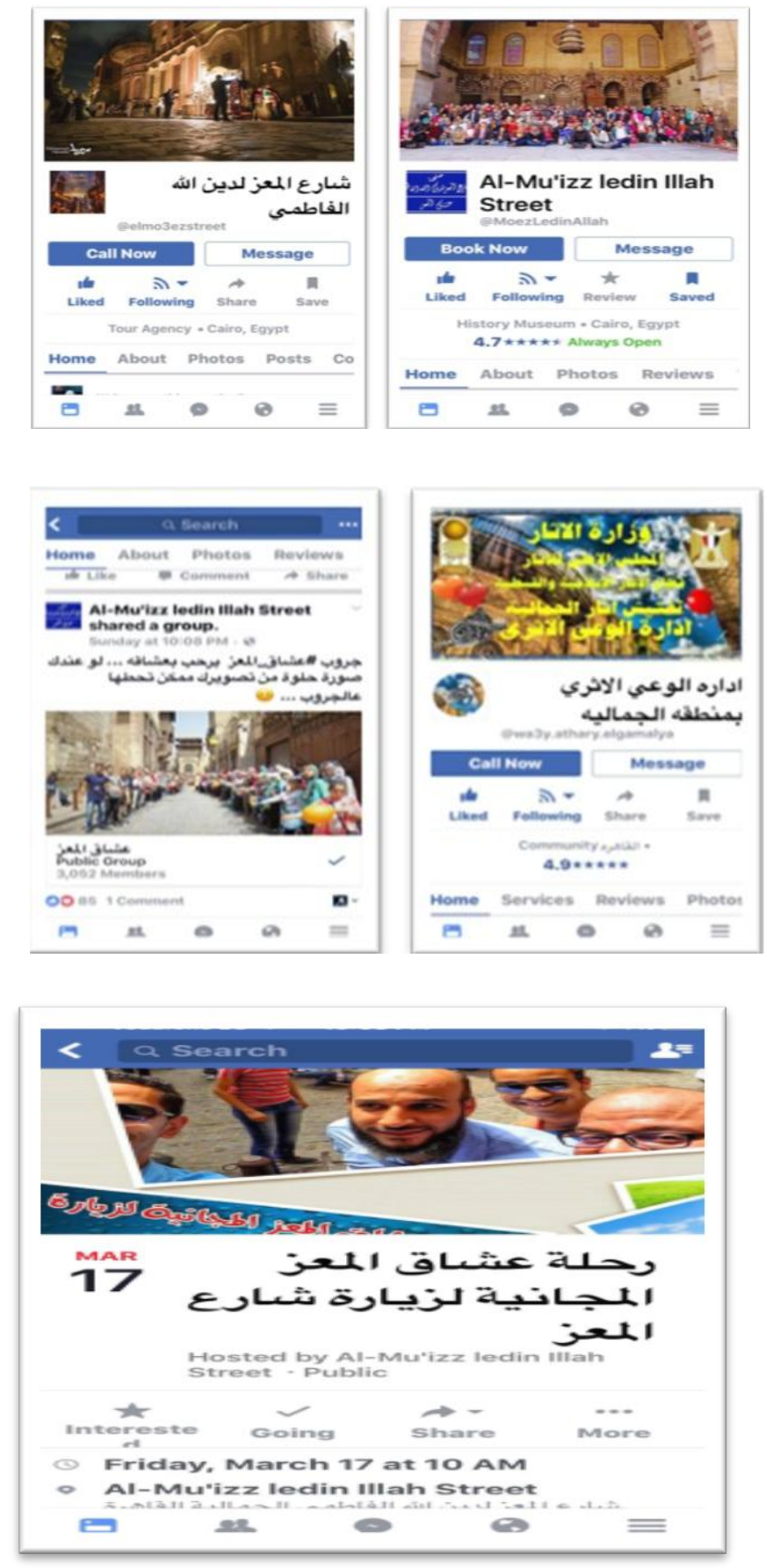

figure (3) Facebook pages

\section{Study Methodology}

The study was a quantitative approach in its nature by surveying some of the Facebook pages. The target population was the tourists who visited Al-Mu'izz Street and Facebook pages. A total of 300 questionnaires were collected and analyzed using SPSS v20.
The aim of this study was to explore the impacts of social media specifically Facebook pages on tourism promotion in Egypt (tourist and heritage sites) from the perspective of a tourist and to show the importance of social media as an important marketing and promoting tool.

\subsection{The objectives are as follows:}

1- Analyzing the visibility, interactivity and profile performance of Al-Mu'izz Street pages on Facebook.

2- Assessing the effect of social media in promoting heritage sites.

3- Presenting the visitor's perception of the benefits of social media (Al-Mu'izz Le din Allah streetpages) as an effective marketing tool.

\subsection{Pilot Test}

The questionnaire was pre-tested by interviewing 3 academic researchers and 2 admins of Al-Mu'izz page and 15 shops owners in Al-Mu'izz Li-din Allah Street. Some corrections to the questionnaire were made to improve its clarity and eliminate some duplicated items.

\subsection{Data collection}

Data was collected through an online questionnaire and a printed form of the questionnaire was also distributed to visitors of Al-Mu'izz street. Visitors of the Al-Mu'izz participated in filling the survey. The questionnaire formed on Survey Monkey (www.surveymonkey.com). It was in English and consisted of 10 questions. The questionnaire questions were derived from some previous similar studies. Data was gathered offline and online in the period between (first of January and till the end of February 2017).A link to the questionnaire 
was distributed on Al-Mu'izz Facebook pages with permission of the admin to gather data online. This method is useful as it gives data at low cost as it is done online. Other advantages of collecting data online are easiness to reach persons online; flexibility to complete the survey at the time suitable for them, additionally, the secrecy of participants is also very important (Evans \& Mathur, 2005 and libweb, 2015). A total of 350 questionnaires were distributed; 50 uncompleted surveys were eliminated leaving 300 usable questionnaires yielding a response rate of $85 \%$.

\section{Results \& Interpretation:}

This part presents the results of a visitor's perspective analysis. The results of the study reveal that there is a great effect of Facebook pages in increasing the number of visitors to Al-Mu'izz Street.

To achieve the first objective, analysis the visibility, interactivity, and profile Performance of Al-Mu'izz pages by evaluating pages KPIs. The online free tool Fan page Karma used, http://www.fanpagekarma.com/, which is suitable for analyzing the effectiveness of social networks profiles, monitor any Facebook page with the best analytics and monitoring tool, Create insight reports and optimize your social media marketing strategy. The study analyzes the most important Facebook pages according to visitor's number and events for example:

1- 'šāqāl-Mo`z(Al-Mu'izzLedinAllahstreet)

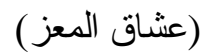

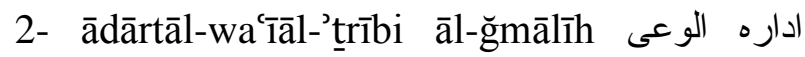
(الاثرى بالجمليه)

3- Šār'āl-mo’zldīnāllahāl-Fāṭ̄ī شار ع المعز لدين)

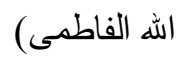

4Šārāāl-mo’zldīnāllahālFāṭī(@elmo3ezstreet) شارع المعز لدين الله (الفاطمىى)

5- Šār'āl-mo’zldīnāllahāl

Fāṭīi@moeaz.fos7tna) شارع المعز لدين الله

الفاطمى)

The study of the Sánchez-Amboage, E., Ludeña-Reyes, A.P. and Viñán-Merecí, C., 2017 has been taken as a reference;"Impact of Religious Tourism in Social Media in the Andean Region of Ecuador".

In terms of the visibility and interactivity of the above-mentioned Facebook pages, (table 1) has shown that "(Al-Mu'izz Le din Allahstreet (Šār’āl-mo'zldīnāllahāl-Fāṭmī)" and "ādārtāl-wa'īāl-'trīibi āl-ğmālīh" are the most visible in Facebook, after that "Šārāalmo’zldīnāllahāl-Fāṭmī” and, Šārāālmo’zldīnāllahāl-Fāṭmī(@elmo3ezstreet) “Šār’āl-mo’zldīnāllahāl-Fāṭmī@moeaz. fos 7 tna).

Generally, the Facebook pages mentioned above attract the interest of 416.98 followers. Regarding the visibility of the abovementioned pages, there is a variation between the number of comments, shares and likes of the analyzed pages, for example, likes in these pages has the highest number. Additionally, the analysis showed that it's important to make a mention of likes related to the photos on the pages. 
Table (1) The interactivityof Facebook pages

\begin{tabular}{|c|c|c|c|c|c|}
\hline 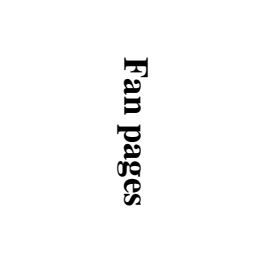 & 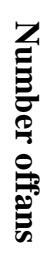 & 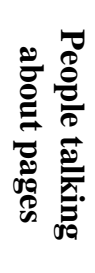 & 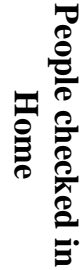 & 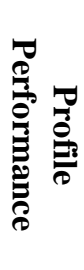 & 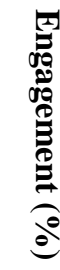 \\
\hline $\begin{array}{c}\text { ‘šāqāl-Mo`z (Al- } \\
\text { Mu'izzLedinIllah } \\
\text { street) }\end{array}$ & $\begin{array}{l}\text { S } \\
\text { w } \\
\text { N }\end{array}$ & $\stackrel{N}{N}_{u}^{N}$ & 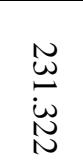 & $\begin{array}{l}\mathfrak{b} \\
\mathfrak{d}\end{array}$ & $\stackrel{N}{w}$ \\
\hline $\begin{array}{l}\text { ādārtāl-wa'īāl- } \\
\text { 'trībi āl-ğmālīh }\end{array}$ & 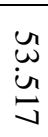 & ur & $\mathrm{i}$ & $\frac{\infty}{\vec{J}}$ & $\frac{w}{d}$ \\
\hline $\begin{array}{c}\text { Šār'āl- } \\
\text { mo’zldīnāllahāl- } \\
\text { Fāṭmī }\end{array}$ & $\begin{array}{l}\text { to } \\
\text { to } \\
\text { N }\end{array}$ & 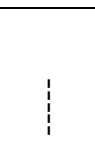 & & 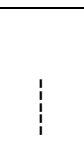 & 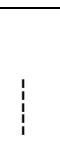 \\
\hline $\begin{array}{c}\text { Šārōāl- } \\
\text { mo’zldīnāllahāl- } \\
\text { Fāṭmī } \\
\text { (@elmo3ezstreet) }\end{array}$ & 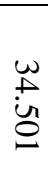 & $\underset{\infty}{\infty}$ & & 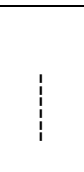 & 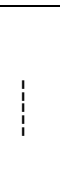 \\
\hline $\begin{array}{c}\text { Šārāāl- } \\
\text { mo’zldīnāllahāl- } \\
\text { Fāṭmī(@ @oeaz.fo } \\
\text { s7tna) }\end{array}$ & $\begin{array}{l}\text { un } \\
\text { w } \\
\text { g }\end{array}$ & $\dot{\omega}_{\tilde{\sigma}}$ & \pm & $\frac{a}{d}$ & iv \\
\hline & \begin{tabular}{l} 
\pm \\
\multirow{2}{0}{}
\end{tabular} & & & & \\
\hline
\end{tabular}

The profile performance of Facebook pages in Table (1), showed that "ādārtāl-wa'īāl-'trībi ālğmālīh" page has the highest profile performance in Facebook with (87\%), followed by "(Al-Mu'izzstreet (Šār’ālmo'zldīnāllahāl-Fāṭmī)" with (69\%) and followed by Šār’āl-mo’zldīnāllahālFāṭmī@moeaz.fos7tna)”with(61\%).

This indicated the overall strength of a Facebook fan page. And According to the information in Table (1), it is shown that the numbers of visitors checked in to Al-Mu'izz street according to the Facebook page reached 232,3322 which indicated the great impact of the pages in their decision to visit Al-Mu'izz street.

The second and third objectives were based on the implementation of surveys, which are designed for gathering digital information and measuring variables (Punch 2003).

According to the data analysis using SPSS v20.98\% of the respondents visit Al-Mu'izz Street regularly, $66.67 \%$ visit the street in groups and 33.3 visits Al-Mu'izz alone. Additionally, $80 \%$ of the respondents visited Al-Mu'izz through events organized by AlMu'izzstreet ('šāāāl-Mo'zpage), which give evidence that visiting the street in groups organized by the Facebook pages are around three times than visit it alone.

$62 \%$ of people participated in the survey showed that Facebook is the most popularsocial sites. While 38 uses other sites, which showed the power of using Facebook in promoting any destination.

$73.7 \%$ indicated that services provided during the visit are matched with what was announced on the page, $16.7 \%$ showed that the service is matched to some extent, 9.7of respondents disagree with that, which indicate that the visitor's trust information available on the facebook pages.

$66.3 \%$ of participants agreed that social media sites were an appropriate source of data about the destination and help to have a great experience about the place you want a visit, $30.0 \%$ strongly agree, while $3.7 \%$ of Respondents' disagree. Most of Respondents' $67 \%$ agreed that reviews and positive comments on social media sites affect their intention to visit the destination, $30 \%$ strongly agree, while $3 \%$ of participants to some extent, which approve that social media can be employed as a reliable data source to revisit intention, as tourists who share their 
experiences affected by reviews when they make tourism preferences.

$75.3 \%$ ofparticipantsstrongly agreed that photos, videos are the most factors that affected their decision to visit a certain destination, while $24.7 \%$ of Respondents' disagree. $74 \%$ affected by images and photos in the page and 64\% affected by word of mouth from relatives and friends, while $20 \%$ of Respondents' agreed.70 \% agreed that Facebook message strongly received through words, descriptionand also by images and photos on the pages, while $20 \%$ of Respondents' agreedand 10\% of Respondents' disagree, which indicate that photos, images and videos play an important role in the intention to visit a destination.

Mostrespondents' $(83.3 \%)$ indicated that there were no obstacles met when browsing the pages of Al-Mu'izz. Street, while $16.7 \%$ of respondents just agreed, which approved that Al Mui'zz Facebook pages are easy to use and well desigined.

\section{Conclusion and Discussion:}

The role of social media on promoting heritages sites in Egypt has not received enough attention from scholars and responsible authorities. This study attempts to fill this gap by studying therole of social media on Tourism promoting to highlight what needs to be considered to effectively promote heritagesites in Egypt. It's significant to show the main results of the surveytoexplore visitor's perception of the benefits of social media. The aim of this study was to improve the understanding of analyzing the visibility, interactivity and profile performance of Facebook pages. Consequently, Identifying the various key performance indicators (KPIs).The results of this study found that the numbers of visitors checked in to Al-Mu'izz street - according to the Facebook page- reached 232, 3322 which prove the great impact of the pages in the decision to visitAl -Mu'izzstreet. The results of the study indicated that most visitors highlighted the importance of promoting heritages sites via social media sites. Moreover, the analysis of data showed that Facebook pages are the most employed social network sites when collecting data on heritage sites. Furthermore, the data analysis highlighted the importance of Facebook pages' comments on the degree of truthfulness and the ability to increase the number of visitors to Al-Mu'izz Street.

The results of this study are consistent with Fotis et al, (2012) who confirmed that social media has a great effect of on destination choice and trust information provided by different websites. It has been also observed in other studies as the study conducted by Gururaja (2015) who found that the majority, almost half of the tourists, did not book their travel withoutreading reviews presented about the destination on the social media sites. These previous results support the finding of the current study in whichreviews and positive comments on social media sites were found to have a great effecton their next visit. Finally, the findings of this study supportthe existence of a positive relationship between social media and promotion of heritage sites. This result is consistent with Wittman, (2012); Bulencea \& Egger (2013) and Sahin \& Sengün (2015) who found that most tourists use social media to sharevideos, photos and experiences.

\section{Recommendation}

According to the study findings, there is a segment of the Facebook market interested in visiting tourist destination. Tourism authority along with tourism companies are advised to take into consideration the impact of these sites on visitors buying intention, 
consequently, reengineer their marketing plans accordingly. The results of this study as well recommend cooperating and supporting the admins of some Facebook pages especially some pages reached more than 231,322 users visited Al-Mu'izz Street because of shared photos, reviews and organized events.

Social media is a good tool for the promotion of domestic tourism, especially, in the times of crisis as most of the visitors of Al-Mu'izz Street are from domestic tourism. In this vein, it is important to ensure the efficient use of the internet for tourism activities. Social media is time and money saving promotional tool for tourism, so it should take more concern from the authorities.

The ministry of tourism should support and encourage the successful social media pages which play a vital role in promoting the touristic places by organizing free tours, posting information and photo about heritages and tourists' sites which not only help to promote the touristic site but also it helps in preserving it. The ministry of tourism should give more concern to their authorized social pages and do more advertises on it and encourage the interaction with their followers.

\section{References}

1. Antoniou, J., (1998). Historic Cairo: a walk through the Islamic city. American Univ. in Cairo Press.

2. Benea, I. A. (2014). Influences of social media on the tourism and hospitality industry. Signature. Bachelor Thesis for Obtaining the Degree Bachelor of Business Administration-Tourism and Hospitality Management.

3. Buted, D.R., Gillespie, N.S., Conti, J.B., Delgado, B.A., Marasigan, R.M.P., Rubico, S.K.A.andFelicen, S.S., (2014). Effects of social media in the tourism industry of Batangas Province. Asia Pacific Journal of Multidisciplinary Research|, 2(3).

4. Bulencea, P. and Egger, R., (2013). Facebook it: evaluation of Facebook's search engine for travel-related information retrieval. In Information and Communication Technologies in Tourism 2014 (pp. 467-480). Springer, Cham.

5. Burgess, S. (2009). Effective Web Presence Solutions for Small Businesses: Strategies for Successful Implementation: Strategies for Successful Implementation. IGI Global.

6. Choustis, E. (2013). The business plan for tourism development of Thessaly, Volos:Research\& Technology Institute of Thessaly. pp. 42-75.

7. Chung, J. Y., \&Buhalis, D. (2008). Information Needs in Online Social Networks. Information Technology and Tourism,10(4), pp.267-281.

8. Dellarocas, C. (2003). The digitization of word of mouth: Promise and challenges of online feedback mechanisms. Management Science, 49(10), pp. 1407-1424.

9. Dickman, S. and Maddock, M. (2000). The business of bed and breakfast. Melbourne: Hospitality Press.

10. Elefant, C., (2011). The power of social media: legal issues \& best practices for utilities engaging social media. Energy LJ, 32, p.1.

11. Escobar-Rodríguez, T., \& Carvajal-Trujillo, E. (2013). An evaluation of Spanish hotel websites: Informational vs. relational strategies. International Journal of Hospitality Management, 33, pp. 228-239.

12. Esu, B. B., \&Ebitu, E. (2010). Promoting an emerging tourism destination. Global Journal of Management and Business Research, 21, pp.21-27.

13. Fotis, J., Buhalis, D.,andRossides, N., 2012. Social media use and impact during the holiday travel planning process (pp. 13-24). Springer-Verlag.

14. Evans, J.R. and Mathur, A., (2005). The value of online surveys. Internet research, 15(2), pp.195-219.

15. Fotis, J., Rossides, N. \&Buhalis, D. (2010). Social media impact on leisure travel: The case of the Russian market and the challenges for the Cyprus tourism industry, preliminary findings. Paper presented at the 3rd Annual EuroMed Conference. EuroMed Academy of Business.

16. Gururaja, R. (2015). Impact of Social Media on Tourism and Hospitality.

17. Guzzo, T., D’Andrea, A., Ferri, F., andGrifoni, P., (2013). A framework to promote and develop a sustainable tourism by using social 
media. In OTM Confederated International Conferences" On the Move to Meaningful Internet Systems".pp. 656-665.

18. Hanna, R., Rohm, A. and Crittenden, V.L., 2011. We're all connected: The power of the social media ecosystem. Business horizons, 54(3), pp.265-273.

19. Hudson, S. and Thal, K., (2013). The impact of social media on the consumer decision process: Implications for tourism marketing. Journal of Travel \& Tourism Marketing, 30(1-2), pp.156160.

20. Hristova, Svetlana; Czepczyński, Mariusz, (2017), Public Space: Between Reimagination and Occupation.

21. Inversini, A., \&Buhalis, D. (2009). Information Convergence in the Long Tail: The Case of Tourism Destination Information. In D. Buhalis, W. Höpken\& U. Gretzel (Eds.), Information and Communication Technologies in Tourism. pp. 381-392.

22. Kaplan, A.M. and Haenlein, M., (2010). Users of the world, unite! The challenges and opportunities of Social Media. Business Horizons, 53(1), pp.59-68

23. Kasavana, M. L., Nusair, K., \&Teodosic, K. (2010). Online social networking: redefining the human web. Journal of Hospitality and Tourism Technology,1(1), pp. 68-82

24. Kim, W. G., Lim, H., \&Brymer, R. A. (2015). The effectiveness of managing social media on hotel performance. International Journal of Hospitality Management, 44, pp.165-171.

25. Klein, H.K. and Myers, M.D., (1999). A set of principles for conducting and evaluating interpretive field studies in information systems. MIS quarterly, pp.67-93

26. Kotler, P., Armstrong, G., Adam, S., and Denize, S. (2014). Principles of marketing. Pearson Australia.

27. Lababidi, Lesly. (2008). Cairo's Street Stories: Exploring the City's Statues, Squares, Bridges, Gardens and sidewalk cafes, The American University in Cairo Press, Egypt.

28. Litvin, S. W., Goldsmith, R. E., \& Pan, B. (2008). Electronic word-of-mouth in hospitality and tourism management. Tourism Management, 29(3), pp. 458-468.

29. Madondo, E., (2016). The influence of social media in promoting the tourism industry in Durban, South Africa (Doctoral dissertation).

30. Matloka, J., \&Buhalis, D. (2010). Destination Marketing through User Personalised Content
(UPC). In U. Gretzel, R. Law \& M. Fuchs (Eds.), Information and Communication Technologies in Tourism 2010. (pp. 519-530). Wien: Springer.

31. Mayfield, A. (2008). What is social media? iCrossing. Retrieved August 25, 2009, from www.icrossing.co.uk/.../What_is_Social_Medi a iCrossing_ebook.pdf

32. Mehrez, Samia (2010), The Literary Atlas of Cairo: One Hundred Years on the Streets of the City, American University in Cairo Press.

33. Merello Tresens, A., (2018). Analysis of the relationship between social media management and eWOM: an exploratory study of the hotel sector.

34. Milano R, Baggio R, Piattelli R (2011) The effects of online social media on tourism websites.In: Law R, Fuchs M, Ricci F (eds) Information and Communication Technologies inTourism, Springer, Wien, pp .471-482

35. Milwood, P. Marchiori, E. Zach, F. (2013). A comparison of social media adoption and use in different countries: A case study of the United States and Switzerland. Journal of Travel and Tourism Marketing (online), 30(2), pp.165-168.

36. Minazzi, R. and Lagrosen, S., (2013). Investigating social media marketing in the hospitality industry: Facebook and European hotels. In Information and Communication Technologies in Tourism. pp.145-157.

37. Mich, L. and Baggio, R., (2015). Evaluating Facebook pages for small hotels: a systematic approach. Information Technology \& Tourism, 15(3), pp.209-231.

38. O Connor, P. (2011). An analysis of the use of Facebook by international hotel chains.

39. Papathanassis, A., \&Knolle, F. (2011). Exploring the adoption and processing of online holiday reviews: A grounded theory approach. Tourism Management, 32(2), pp. 215-224

40. Park, J., (2015). The Impact of Different Types of Media on Tourists' Behavioral Intentions.

41. Parra-Lopez, E., Bulchand-Gidumal, J., Gutierrez-Tano, D., \& Diaz-Armas, R. (2010). Intentions to use social media in organizing and taking vacation trips. Computers in Human Behavior, (In Press: DOI: 10.1016/j.chb.2010.05.022).

42. Popesku, J., (2014). Social media as a tool of destination marketing organisations. Sinteza 2014-Impact of the Internet on Business 
Activities in Serbia and Worldwide, pp.715721.

43. Punch, K., 2003. Survey research: The basics. Sage.

44. Rodrigues, E., (2017). The Information and Promotion of Rural Tourism in the Globalised Era: The Case of Madeira Island. In Tourism, Culture and Heritage in a Smart Economy,pp. 437-453.

45. Sahin, G. and Sengün, G., (2015). The effects of social media on tourism marketing: a study among university students. Management and Administrative Sciences Review, 4(5), pp.772786

46. Sánchez-Amboage, E., Ludeña-Reyes, A.P. and Viñán-Merecí, C., (2017). Impact of Religious Tourism in Social Media in the Andean Region of Ecuador: The Case of the Pilgrimage of the Virgin of El Cisne and the Trade Fair of Loja. In Media and Metamedia Management (pp. 303-308). Springer International Publishing.

47. Sayyed, Nezar. (1981). treets of Islamic Cairo: A Configuration of Urban Themes and Patterns, Aga Khan Program for Islamic Architecture. (p.93)

48. Schmallegger, D., \& Carson, D. (2008). Blogs in tourism: Changing approaches to information exchange. Journal of Vacation Marketing,14, pp.99-110.

49. Sedky, Ahmed, (2009). Living with Heritage in Cairo: Area Conservation in the Arab-Islamic City, The American University in Cairo Press, Egypt, p.184.

50. Seth, G., (2012). Analyzing the effects of social media on the hospitality industry.

51. Sigala, M., 2011. eCRM 2.0 applications and trends: The use and perceptions of Greek tourism firms of social networks and intelligence. Computers in Human Behavior, 27(2), pp.655-661.

52. Wan, C.-S. (2002). The web sites of international tourist hotels and tour wholesalers in Taiwan. Tourism Management, 23(2), pp.155-160.

53. Waxer, C. (2012). Tourism boards use social media for broader reach and better targeting.Tourism and social media (Online), Available: http://search.proquest.com (Accessed 28 March 2015).

54. Weinberg, T. (2009). The New Community Rules: Marketing on the Social Web. Sebastopol, CA: O’Reilly Media Inc.
55. Werthner, H., \& Ricci, F. (2004). E-commerce and tourism. Communications of the ACM, 47(12), pp.101-105

56. Wong, J., \& Law, R. (2005). Analysing the intention to purchase on hotel websites: a study of travelers to Hong Kong. International Journal of Hospitality Management, 24(3), 311-329. Available from: http://doi.org/10.1016/j.ijhm. (Accessed on 10April 2016).

57. Wittman, A., Halm, J., Tullier, C., D’Mello, A., Bartels, R., Lamboley, D., Smith, T., Nelle, R., Hartless, M.L., Gockenbach, J. and Bucholtz, B., (2012). Use of social networking tools in unit 5. SNT White Paper. Unit, 5.

58. Xiang, Z., \&Gretzel, U. (2010). Role of social media in online travel information search. Tourism Management, 31(2), pp.179-188.

59. Ye, Q., Law, R., \& Gu, B. (2009). The impact of online user reviews on hotel room sales. International Journal of Hospitality Management, 28(1), 180-182. Available from: http://doi.org/10.1016/j.ijhm.2008.06.011 (Accessed on22 March 2016)

60. Zeng, B. and Gerritsen, R., 2014. What do we know about social media in tourism? A review. Tourism Management Perspectives, 10, pp.2736.

61. https://www.quintly.com/blog/most-importantfacebook-kpis. (Accessedon March 2017).

62. https://www.fanpagekarma.com.(Accessed onMarch 2017).

63. https://megalytic.com/blog/identifyingreporting-facebook-kpis .(Accessed on April 2017). 